\title{
HUBUNGAN PENGARUH ASAP ROKOK DENGAN TERJADINYA KELUHAN PADA MATA
}

\author{
1)Alvin Renaldo Tanjaya \\ ${ }^{2)}$ Laya Rares \\ 2)JSM Saerang
}

\author{
${ }^{1}$ Kandidat Skripsi Fakultas Kedokteran Universitas Sam Ratulangi Manado \\ ${ }^{2}$ Bagian SMF Mata,Fakultas Kedokteran Universitas Sam Ratulangi Manado \\ Email: www_alv1n@yahoo.co.id
}

\begin{abstract}
Eye is one of the reflection of physical, mentality and spirituality. Survey by WHO revealed that $1 / 3$ of world's population especially adult is smoker $(57 \%$ men and $43 \%$ women). Most of smokers had no awareness of the danger of smoking. About 4000 types of chemicals substance and 60 carcinogenic compounds contain in a cigarette and addictive. This research aim to determine the relationship between smoke exposure with complaints that occur in eyes. The study wasan analytical method retrospectively that conducted from November to December 2012 at Terminal Malalayang using. The data was collected using a questionnaire with 100 people responden (50 smoker and 50 nonsmoker). The result showed that 32 responden is smoker with a moderate smokers (11-21 bars) and 29 responden is a passive smoker. Data was analyze with ANOVA test that indicate increasing complaint for smoker group than non smoker group that consist of red eye (0.000), eye irritation (0.000), gritty eyes $(0.000)$, eye lacrimation $(0.000)$, itchy eyes (0.000) and increased frequency blink (0.000).
\end{abstract}

Keywords: Smokers, non-smokers, eye complaint

Abstrak : Mata merupakan cerminan dari kondisi fisik, mental dan spiritual. Menurut hasil survey dari WHO sepertiga dari penduduk di dunia terutama pada populasi dewasa adalah perokok (dimana 57\% diantaranya adalah laki-laki dan 43\% diantaranya adalah perempuan). Perokok kebanyakan kurang memiliki pengetahuan tentang bahaya merokok...Tercatat tidak kurang dari 4000 jenis zat kimia yang terkandung dalam sebatang rokok dan 60 zat di antaranya bersifat karsinogenik dan bersifat adiktif. Tujuan dari penelitian ini adalah untuk mengetahui bagaimanakah hubungan antara paparan asap rokok terhadap keluhan yang ditimbulkan pada mata. Penelitian ini dilakukan sejak bulan November hingga bulan Desember 2012 di Terminal malalayang dengan menggunakan metode Analitik retrospektif. Pengumpulan data dilakukan menggunakan Kuisioner dengan jumlah responden 100 orang yang terdiri dari 50 perokok dan 50 bukan perokok. Dari hasil penelitian didapatkan Sebagian besar sampel perokok yang ada di terminal malalayang merupakan perokok sedang (11-21 batang) yang terdiri dari 32 orang dan sebanyak 29 orang yang dikategorikan sebagai perokok pasif. Berdasarkan uji Anova Terjadi peningkatan keluhan mata pada kelompok perokok di bandingkan dengan kelompok bukan perokok yang meliputi mata merah $(0,000)$, mata perih $(0,000)$, mata berpasir $(0,000)$, mata lakrimasi $(0,000)$, mata gatal $(0,000)$ dan peningkatan frekuensi kedip $(0,000)$.

Kata kunci : Perokok, bukan perokok, keluhan pada mata 
Menurut hasil survey dari WHO sepertiga dari penduduk di dunia terutama pada populasi dewasa adalah perokok (dimana 57\% diantaranya adalah laki-laki dan 43\% diantaranya adalah perempuan). Pada zaman sekarang, satu dari sepuluh kematian didunia adalah akibat rokok dan jumlah kematian mencapai 500 juta orang per tahun. Dalam setiap enam detik terdapat satu kematian akibat rokok. ${ }^{1}$

Tingginya persentase penduduk Indonesia yang mempunyai kebiasaan merokok, kesehatan menjadi salah satu factor yang tidak bisa dikesampingkan tercatat tidak kurang dari 4000 jenis zat kimia yang terkandung dalam sebatang rokok dan 60 zat di antaranya bersifat karsinogenik dan bersifat adiktif. ${ }^{2}$ Perokok kebanyakan kurang memiliki pengetahuan tentang bahaya merokok. Mereka tidak menyadari bahwa merokok akan menurunkan kualitas hidup dan penampilan. ${ }^{3}$

Data dari badan pusat statistic menunjukkan bahwa di jawa barat pada tahun 2007 terdapat 11.207.720 perokok, mulai dari umur 10 tahun ke atas. Jumlah itu meningkat dibandingkan dengan data tahun 2006 yaitu 10.124 .117 perokok. ${ }^{3}$ Rokok yang belum dinyalakan mengandung nikotin, karsinogen dan toksin lain yang dapat menyebabkan penyakit gusi dan kanker mulut. Jika rokok di nyalakan, maka asap resultan mengandung nikotin, CO, dan 4000 komponen lain sebagai hasil dari volatisasi, pirolisis, dan pirosintesis tembakau, serta aditif kimia lain yang digunakan dalam memproduksi rokok. ${ }^{4}$

Mata merupakan cerminan dari kondisi fisik, mental dan spiritual. Indera penglihat ini merupakan salah satu ekspresi hati yang tidak dapat berbohong. Mata dapat bercerita tentang apa

yang sedang dirasakan oleh seseorang. ${ }^{5}$ Di dalam wadahnya yang protektif, setiap mata memiliki lapisan reseptor, sistem lensa yang memfokuskan cahaya ke reseptor tersebut, serta sistem saraf yang menghantarkan impuls dari reseptor ke otak. ${ }^{6}$

\section{METODE PENELITIAN}

Penelitian ini menggunakan metode Analitik retrospektif dengan menggunakan desain Cross sectional. Penelitian ini dilakukan di terminal malalayang manado dengan Jumlah sampel 100 orang yang terdiri dari 50 kelompok perokok dan 50 bukan perokok Waktu penelitian berlangsung dari bulan November-Desember 2012. Dengan pengumpulan data menggunakan lembaran kuisioner yang berupa lembaran Tanya jawab. Pengkodingan kuesioner sesuai dengan variable yang ada dalam kuesioner, kemudian dibuatkan daftar koding untuk memindahkan hasil pengisian daftar koding kuesioner program pemasukan data ke dalam program SPSS sesuai dengan karakteristik serta skala masing-masing variabel. Dan dalam pengolaan data menggunakan uji Anova.

\section{HASIL PENELITIAN}

Berdasarkan hasil penelitian yang dilakukan sejak bulan November hingga bulan Desember 2012 di Terminal malalayang dengan jumlah responden 100 orang didapatkan hasil sebagai berikut:

\section{a. Distribusi Responden Menurut Usia}

Tabel 1. Distribusi responden menurut usia 


\begin{tabular}{lll}
\hline Usia & Jumlah & $\%$ \\
\hline$<21$ & 12 & 12,0 \\
$21-35$ & 41 & 41,0 \\
$>35$ & 47 & 47,0 \\
\hline Total & 100 & 100,0 \\
\hline
\end{tabular}

b. Distribusi berdasarkan tipe perokok

Tabel 2. Distribusi responden menurut tipe perokok

1) Tabel 2 Klasifikasi menurut Tipe perokok

\begin{tabular}{lll}
\hline Tipe perokok & Jumlah & $\%$ \\
\hline Perokok sangat berat (>31 batang) & 10 & 20,0 \\
Perokok berat (21-30 batang) & 6 & 12,0 \\
Perokok sedang (11-21 batang) & 32 & 64,0 \\
Perokok ringan (<10 batang) & 2 & 4,0 \\
\hline Total & 50 & 100,0 \\
\hline
\end{tabular}

c. Distribusi Responden berdasarkan keluhan

Tabel 5. Distribusi responden menurut keluhan

1) Tabel $3.1 \quad$ Klasifikasi menurut mata merah

\begin{tabular}{|c|c|c|c|c|c|}
\hline Mata merah & perokok & $\%$ & $\begin{array}{l}\text { Bukan } \\
\text { perokok }\end{array}$ & $\%$ & sign \\
\hline Tidak & 7 & 14,0 & 25 & 50,0 & 0,000 \\
\hline Sekali dalam sebulan & 29 & 58,0 & 20 & 40,0 & \\
\hline $\begin{array}{l}2-4 \quad \text { kali dalam } \\
\text { sebulan }\end{array}$ & 6 & 12,0 & 5 & 10,0 & \\
\hline $\begin{array}{l}>\quad 4 \quad \text { kali dalam } \\
\text { sebulan }\end{array}$ & 8 & 16,0 & 0 & 0 & \\
\hline Total & 50 & 100,0 & 50 & 100,0 & \\
\hline
\end{tabular}


2) Tabel $3.2 \quad$ Klasifikasi menurut mata perih

\begin{tabular}{|c|c|c|c|c|c|}
\hline Mata Perih & perokok & $\%$ & $\begin{array}{l}\text { Bukan } \\
\text { perokok }\end{array}$ & $\%$ & sign \\
\hline Tidak & 5 & 10,0 & 34 & 68,0 & 0,000 \\
\hline Sekali dalam sebulan & 29 & 58,0 & 11 & 22,0 & \\
\hline $\begin{array}{l}2-4 \text { kali dalam } \\
\text { sebulan }\end{array}$ & 6 & 12,0 & 4 & 8,0 & \\
\hline $\begin{array}{l}>\quad 4 \text { kali } \text { dalam } \\
\text { sebulan }\end{array}$ & 10 & 20,0 & 1 & 2,0 & \\
\hline Total & 50 & 100,0 & 50 & 100,0 & \\
\hline
\end{tabular}

3) Tabel 3.3 Klasifikasi menurut mata gatal

\begin{tabular}{|c|c|c|c|c|c|}
\hline Mata Gatal & perokok & $\%$ & $\begin{array}{l}\text { Bukan } \\
\text { perokok }\end{array}$ & $\%$ & sign \\
\hline Tidak & 4 & 8,0 & 28 & 56,0 & 0,000 \\
\hline Sekali dalam sebulan & 23 & 46,0 & 15 & 30,0 & \\
\hline $\begin{array}{l}2-4 \text { kali dalam } \\
\text { sebulan }\end{array}$ & 15 & 30,0 & 5 & 10,0 & \\
\hline $\begin{array}{l}>\quad 4 \text { kali dalam } \\
\text { sebulan }\end{array}$ & 8 & 16,0 & 2 & 4,0 & \\
\hline Total & 50 & 100,0 & 50 & 100,0 & \\
\hline
\end{tabular}

4) Tabel $3.4 \quad$ Klasifikasi Menurut Mata Kering

\begin{tabular}{llllll}
\hline Mata Kering & perokok & $\%$ & $\begin{array}{l}\text { Bukan } \\
\text { perokok }\end{array}$ & $\%$ & sign \\
\hline Tidak & 5 & 10,0 & 32 & 64,0 & 0,000 \\
$\begin{array}{l}\text { Sekali dalam sebulan } \\
2-4 \quad \text { kali dalam }\end{array}$ & 10 & 52,0 & 10 & 20,0 & \\
$\begin{array}{l}\text { sebulan } \\
\begin{array}{l}\quad 4 \quad \text { kali dalam } \\
\text { sebulan }\end{array}\end{array}$ & 9 & 18,0 & 6 & 12,0 & \\
\hline Total & & & 2 & 4,0 & \\
\hline
\end{tabular}


5) Tabel 3.5 Klasifikasi Menurut Mata Lakrimasi

\begin{tabular}{llllll}
\hline Mata Lakrimasi & perokok & $\%$ & $\begin{array}{l}\text { Bukan } \\
\text { perokok }\end{array}$ & $\%$ & sign \\
\hline Tidak & 6 & 12,0 & 29 & 58,0 & 0,000 \\
Sekali dalam sebulan & 22 & 44,0 & 12 & 24,0 & \\
2-4 kali dalam sebulan & 6 & 12,0 & 5 & 10,0 & \\
$>$ 4 kali dalam sebulan & 16 & 32,0 & 4 & 8,0 & \\
\hline Total & 50 & 100,0 & 50 & 100,0 & \\
\hline
\end{tabular}

6) Tabel 3.6 Klasifikasi Menurut Mata Berpasir

\begin{tabular}{|c|c|c|c|c|c|}
\hline Mata Berpasir & perokok & $\%$ & $\begin{array}{l}\text { Bukan } \\
\text { perokok }\end{array}$ & $\%$ & sign \\
\hline Tidak & 6 & 12,0 & 27 & 54,0 & 0,000 \\
\hline Sekali dalam sebulan & 22 & 44,0 & 17 & 34,0 & \\
\hline $\begin{array}{l}2-4 \quad \text { kali dalam } \\
\text { sebulan }\end{array}$ & 14 & 28,0 & 6 & 12,0 & \\
\hline $\begin{array}{lcc}>\quad 4 & \text { kali } & \text { dalam } \\
\text { sebulan } & & \\
\end{array}$ & 8 & 16,0 & 0 & 0 & \\
\hline Total & 50 & 100,0 & 50 & 100,0 & \\
\hline
\end{tabular}

f. Distribusi responden berdasarkan frekuensi kedip

Tabel 6 Distribusi berdasarkan Peningkatan Frekuensi kedip

\begin{tabular}{llllll}
\hline $\begin{array}{l}\text { Peningkatan } \\
\text { Frekuensi kedip }\end{array}$ & Perokok & $\%$ & $\begin{array}{l}\text { Bukan } \\
\text { perokok }\end{array}$ & $\%$ & sign \\
\hline Ya & 38 & 76,0 & 13 & 26,0 & 0,000 \\
Tidak & 12 & 24,0 & 37 & 74,0 & \\
\hline Total & 50 & 100,0 & 50 & 100,0 & \\
\hline
\end{tabular}

BAHASAN

Berdasarkan hasil yang di teliti, pada kelompok perokok dan bukan perokok di terminal malalayang sampel terbanyak yang diambil adalah $>35$ tahun dengan jumlah 47 orang(47\%) terjadi peningkatan keluhan pada perokok di bandingkan dengan bukan perokok. Karena sebagian besar dari kelompok bukan perokok tidak terdapat keluhan dan terjadi peningkatan di setiap keluhan khususnya pada skala sekali dalam sebulan. di dapatkan jumlah batang rokok 
yang dikonsumsi para perokok sebagian besar di terminal malalayang berkisar 11-21 batang yang diklasifikasikan sebagai perokok sedang.

Dengan menggunakan uji Anova didapatkan nilai signifikan antara merokok dan keluhan mata merah $(\mathrm{F}=0,000)$, perih $(\mathrm{F}=0,000)$, gatal $(\mathrm{F}=0,000)$, kering $(\mathrm{F}=0,000)$, lakrimasi $(\mathrm{F}=0,000)$, berpasir $(\mathrm{F}=0,000)$, peningkatan frekuensi kedipan $(\mathrm{f}=0.000)$. dengan ketentuan apabila nilai signifikansi kurang dari $\mathrm{df}=1$ berarti mempunyai nilai bermakna (hubungan/pengaruh) dan apabila lebih dari nilai tersebut nilainya tidak bermakna( tidak memiliki hubungan/pengaruh). Dari hasil tersebut, menunjukkan bahwa terdapat hubungan keluhan asap rokok dengan terjadi keluhan pada mata .Pada penelitian serupa yang dilakukan jansen bahwa kelompok perokok lebih banyak terjadi peningkatan keluhan dibandingkan dengan yang tidak dengan $(\mathrm{p}<0,05)$ sedangkan peningkatan frekuensi kedip $(\mathrm{p}<0,001) .{ }^{7}$ Dengan kata lain penelitian sebelumnya memiliki hubungan antara merokok dengan terjadinya keluhan pada mata, yaitu terjadi peningkatan keluhan pada mata pada kelompok perokok dibandingkan dengan kelompok bukan perokok

\section{SIMPULAN}

Berdasarkan hasil penelitian dan pembahasan yang telah dipaparkan di atas dapat disimpulkan bahwa:

1 Terjadi peningkatan keluhan mata pada kelompok perokok di bandingkan dengan kelompok bukan perokok

2 Terdapat hubungan asap rokok dengan terjadinya keluhan pada mata yang meliputi mata merah, mata perih, mata berpasir, mata lakrimasi, mata gatal dan peningkatan frekuensi kedip

\section{UCAPAN TERIMA KASIH}

Ucapan terima kasih ditujukan kepada dr. Vera Sumual, SpM dan dr. Yamin Tongku, SpM selaku penguji skripsi yang telah memberikan banyak masukan dan saran, serta pihak-pihak yang secara langsung atau tidak langsung telah menumbuhkan gagasan dan ide kepada penulis

\section{DAFTAR PUSTAKA}

1. WHO,2008 Who report on the global tobacco epidemic.WHO. avalaible from :http: //www.who.int/tobacco/mpower/mpower_report_full_2008.pdf

2. Gondodiputro, S, 2007. Bahaya Tembakau dan Bentuk-bentuk sediaan Tembakau. Bagian Ilmu Kesehatan Masyarakat Fakultas Kedokteran Universitas Padjajaran. Available:from: http://resources.unpad.ac.id/unpadcontent/uploads/publikasidosen/Rokok.PDF

3. Sastrawijaya AT. Pencemaran Lingkungan. Edisi revisi ke-2. Jakarta; 2009. hal. 216

4. Sudoyo AW. Setiyohadi B. Alwi I. K Ma.Setiati S. IPD jilid 1. Edisi V. Jakarta: InternaPublishing; 2009. hal. 86

5. Mahendra B. Tubuh Anda Cermin Kesehatan Anda. Jakarta; 2010. hal. 26,53-56

6. Ganong FW. Buku Ajar Fisiologi Kedokteran. Edisi 22. Jakarta: EGC; 2008. hal. 155-156 
7. Jansen. Dampak paparan merokok terhadap frekuensi mengedip dan keluhan yang dirasakan pada mata pada pria usia 20 - 40 tahun di kelurahan Kesawan Medan. Universitas Sumatera Utara Medan;2009 